\title{
ANALISIS KADAR RESIDU PESTISIDA (KLORPIRIFOS) DALAM LALAPAN BERDASARKAN CARA PENGOLAHAN
}

\author{
Khiki Purnawati Kasim \\ Jurusan Kesehatan Lingkungan Poltekkes Kemenkes Makassar
}

\begin{abstract}
ABSTRAK
Senyawa klorpirifos banyak digunakan untuk mengendalikan hama terutama komoditi sayur-sayuran yang dijadikan lalapan. Lalapan umumnya dikomsumsi mentah dan terlebih dahulu dicuci dengan air ataupun dicelup pada air panas. Tujuan penelitian adalah untuk menganalisa residu pestisida (klorpirifos) dalam lalapan berdasarkan cara pengolahan. Jenis penelitian adalah deskriptif yaitu mengidentifikasi residu klorpirifos dalam lalapan kubis dan kacang panjang dengan cara pengolahan pencucian air bersih dan pencelupan air panas. Kadar residu klorpirifos diketahui melalui pemeriksaan laboratorium di Balai Besar Laboratorium Kesehatan. Sampel dalam penelitian ini adalah 12 sampel yaitu kubis dan kacang panjang tanpa perlakuan, lalapan yang dicuci dengan air bersih dan lalapan yang dicelup air panas. Hasil penelitian diketahui rerata kadar residu klorpirifos pada kubis segar sebesar $0.004 \mathrm{mg} / \mathrm{kg}$ dan kacang panjang segar sebesar 0.045 $\mathrm{mg} / \mathrm{kg}$. Rerata kadar residu klorpirifos dalam lalapan dengan pencucian air bersih pada kubis sebesar $0.0005 \mathrm{mg} / \mathrm{kg}$ dan kacang panjang sebesar $0.0145 \mathrm{mg} / \mathrm{kg}$. Rerata kadar klorpirifos dalam lalapan dengan pencelupan air panas pada kubis sebesar $0.0005 \mathrm{mg} / \mathrm{kg}$ dan kacang panjang sebesar $0.005 \mathrm{mg} / \mathrm{kg}$. Disimpulkan bahwa pada lalapan kubis terdapat penurunan kadar residu klorpirifos $84 \%$ pada pencucian air bersih dan $90 \%$ pada pencelupan air panas, sedangkan pada lalapan kacang panjang dengan pencucian air bersih terdapat penurunan $65 \%$ dan pencelupan air panas terdapat penurunan $88 \%$. Sehingga disarankan kepada pedagang makanan yang terdapat lalapan dalam menu jualannya sebaiknya mengolah lalapan dengan pencelupan pada air panas.
\end{abstract}

Kata Kunci : klorpirifos, residu, lalapan

\section{PENDAHULUAN}

Berdasarkan data Dirjen Prasarana dan Sarana direktorat Pupuk dan Pestisida Kementerian Pertanian tahun 2011 diketahui bahwa terjadi peningkatan jumlah penggunaan pestisida dari tahun ke tahun dengan jumlah paling banyak yang digunakan adalah insektisida.

Pestisida yang banyak digunakan untuk mengendalikan hama tanaman umumnya berupa pestisida organik sintetik. Pestisida ini berdasarkan atas struktur kimianya dibedakan atas organoklorin, organofosfat, karbamat, dan piretrin. (Prijatno (2009) dalam Zainul Fadilah (2013)). Selain membantu petani dalam mengatasi gangguan hama, penggunaan pestisida yang kurang bijaksana akan menimbulkan akibat yang merugikan kesejahteraan manusia sendiri. Penggunaan pestisida yang tidak tepat akan membawa akibat negatif, seperti masalah residu pestisida pada komoditi pertanian, terutama komoditi sayur-sayuran terlebih lagi sayuran yang biasa dikomsumsi mentah seperti dalam Ialapan.

Menurut Penelitian di Laboratorium Pengujian Pestisida UPTD Balai Proteksi Tanaman Pangan dan Hortikultura tahun 2013, pada sayuran kol siap santap di Kantin Jasper Unhas Makassar dan di pasar Terong Kota Makassar, ditemukan adanya residu klorpirifos $\leq 0,1 \mathrm{mg} / \mathrm{kg}$ dalam kubis berdasarkan batas deteksi pada alat kromatografi gas yang digunakan. Meskipun hasil tersebut masih dibawah Batas Maksimum Residu (BMR) SNI tahun 2008 yaitu $1 \mathrm{mg} / \mathrm{kg}$ dan masih dikategorikan aman, hal ini perlu diwaspadai mengingat bahaya klorpirifos pada manusia, seperti efek terhadap sistem saraf pusat mencakup kebingungan, mengantuk, depresi, susah berkonsentrasi, gagap dalam berbicara, insomnia, mimpi buruk, dan menjadi gila (Elvinali, 2013).

Lalapan kubis dan kacang panjang sebelum dikonsumsi dalam keadaan mentah umumnya dicuci terebih dahulu dengan air ataupun melalui proses pemanasan seperti direbus sebentar ataupun dicelup pada air panas. Selain itu sayuran tersebut biasanya dimasak tanpa di kupas sehingga kemungkinan terbawanya pestisida yang menempel di permukaan sayuran sangat besar karena dapat menyebabkan pestisida melekat lebih erat dan susah larut saat di cuci.

Oleh karena itu, sayuran seperti kubis dan kacang panjang perlu diperhatikan, baik dari tingkat residu pestisida maupun cara pengolahannya. Berdasarkan hal tersebut, maka dibuatlah proposal ini sebagai bahan informasi tentang pengolahan lalapan 
kubis dan kacang panjang agar aman dari pestisida.

\section{BAHAN DAN METODE}

Jenis penelitian adalah deskriptif yaitu mengidentifikasi residu klorpirifos dalam lalapan kubis dan kacang panjang yang sayurannya berasal dari pedagang di Pasar Terong Kota Makassar merupakan salah satu sumber pasokan sayur sebagai bahan baku lalapan. Penelitian dilakukan di kampus Poltekkes Makassar Jurusan Kesehatan Lingkungan dengan sampel sebanyak 12 sampel, 2 sampel yaitu sayur kubis dan kacang panjang tanpa perlakuan yakni sayuran segar tanpa dicuci dan dicelup air panas, 2 sampel yaitu lalapan kubis dan kacang panjang dengan perlakuan dicuci dengan air dan 2 sampel lalapan kubis dan kacang panjang dengan perlakuan dicuci dan dicelup ke air panas. Pemeriksaan dilakukan replikasi sebanyak dua kali. Pemeriksaan kadar residu pestisida (klorpirifos) dilakukan pada Balai Besar Laboratorium Kesehatan Makassar dengan metode KG (Kromatografi Gas). Data yang diperoleh dari hasil pemeriksaan laboratorium dan pengamatan di lapangan dianalisis dan dihitung secara manual dan disajikan dalam bentuk tabel dan narasi.

\section{HASIL DAN PEMBAHASAN}

Hasil analisis residu pestisida (Chlorpyrifos)dapat dilihat sebagai berikut:

1. Kadar Residu Pestisida (Chlorpyrifos) Dalam Sayur Segar Tanpa Perlakuan

Tabel 1

Hasil Pemeriksaan Residu Pestisida (Chlorpyrifos) Pada Sayur Segar Tanpa Perlakuan

\begin{tabular}{cccc}
\hline \multirow{2}{*}{ No } & \multirow{2}{*}{ Jenis Sampel } & \multicolumn{2}{c}{ Kadar Residu Pestisida (Chlorpyrifos) $\mathbf{~ m g} / \mathbf{k g}$} \\
\cline { 3 - 4 } & & Kubis & Kacang Panjang \\
\hline $\mathbf{1}$ & Perlakuan I & 0.005 & 0.022 \\
$\mathbf{2}$ & Perlakuan II & 0.003 & 0.068 \\
& Jumlah & 0.008 & 0.090 \\
& Rerata & 0.004 & 0.045 \\
\hline
\end{tabular}

Pada tabel 5.1 diketahui rerata kadar residu pestisida (chlorpyrifos) pada sayur segar (tanpa perlakuan)dalam sayur kubis $0.004 \mathrm{mg} / \mathrm{kg}$, sedangkan rerata hasil pemeriksaan kadar residu pestisida (chlorpyrifos) pada sayur kacang panjang sebesar $0.045 \mathrm{mg} / \mathrm{kg}$.

2. Kadar Residu Pestisida (Chlorpyrifos) Dalam Lalapan Dengan Pencucian Air Bersih

Tabel 2

Hasil Pemeriksaan Residu Pestisida (Chlorpyrifos) Dalam Lalapan Dengan Pencucian Air Bersih

\begin{tabular}{cccc}
\hline \multirow{2}{*}{ No } & Jenis Sampel & \multicolumn{2}{c}{ Kadar Residu Pestisida (Chlorpyrifos) $\mathbf{~ m g / k g}$} \\
\cline { 3 - 4 } & & Kubis & Kacang Panjang \\
\hline $\mathbf{1}$ & Perlakuan I & $<0.001$ & 0.009 \\
$\mathbf{2}$ & Perlakuan II & 0.001 & 0.020 \\
& Jumlah & 0.001 & 0.029 \\
& Rerata & 0.0005 & 0.0145 \\
\hline
\end{tabular}

Pada tabel 5.2 rerata kadar residu pestisida (chlorpyrifos) dalam lalapan dengan pencucian air bersih pada kubis $0.0005 \mathrm{mg} / \mathrm{kg}$, sedangkan kacang panjang sebesar 0.0145 $\mathrm{mg} / \mathrm{kg}$.

3. Kadar Residu Pestisida (Chlorpyrifos) Dalam Lalapan Dengan Pencelupan Pada Air Panas 
Tabel 3

Hasil Pemeriksaan Residu Pestisida (Chlorpyrifos) Dalam Lalapan Dengan Pencelupan Pada Air Panas

\begin{tabular}{cccc}
\hline \multirow{2}{*}{ No } & \multirow{2}{*}{ Jenis Sampel } & \multicolumn{2}{c}{ Kadar Residu Pestisida (Chlorpyrifos) $\mathbf{~ m g / k g}$} \\
\cline { 3 - 4 } & & Kubis & Kacang Panjang \\
\hline $\mathbf{1}$ & Perlakuan I & 0.001 & 0.003 \\
$\mathbf{2}$ & Perlakuan II & $<0.001$ & 0.007 \\
& Jumlah & 0.001 & 0.010 \\
\hline & Rerata & 0.0005 & 0.005 \\
\hline
\end{tabular}

Pada tabel 5.3 rerata kadar residu pestisida (chlorpyrifos) dalam lalapan dengan pencelupan air panas pada kubis $0.0005 \mathrm{mg} / \mathrm{kg}$, sedangkan pada kacang panjang sebesar $0.005 \mathrm{mg} / \mathrm{kg}$.

4. Kadar Residu Pestisida (Chlorpyrifos) Dalam Lalapan Kubis Berdasarkan Cara Pengolahan

Tabel 4

Hasil Pemeriksaan Residu Pestisida (Chlorpyrifos) Dalam Lalapan Kubis Berdasarkan Cara Pengolahan

\begin{tabular}{|c|c|c|c|c|c|c|c|c|}
\hline \multirow{4}{*}{ No } & \multirow{4}{*}{ Jenis Sampel } & \multicolumn{7}{|c|}{ Cara Pengolahan Lalapan Kubis } \\
\hline & & \multirow{3}{*}{$\begin{array}{c}\text { Tanpa } \\
\text { Perlakuan } \\
\text { (Sayur } \\
\text { Segar) }\end{array}$} & \multicolumn{3}{|c|}{ Pencucian Air Bersih } & \multicolumn{3}{|c|}{ Pencelupan Air Panas } \\
\hline & & & \multirow{2}{*}{$\begin{array}{c}\text { Kadar } \\
(\mathrm{kg} / \mathrm{mg})\end{array}$} & \multicolumn{2}{|c|}{ Penurunan } & \multirow{2}{*}{$\begin{array}{c}\text { Kadar } \\
(\mathrm{mg} / \mathrm{kg})\end{array}$} & \multicolumn{2}{|c|}{ Penurunan } \\
\hline & & & & $\mathrm{kg} / \mathrm{mg}$ & $\%$ & & $\mathrm{~kg} / \mathrm{mg}$ & $\%$ \\
\hline 1 & Perlakuan I & 0.005 & $<0.001$ & 0.005 & 100 & 0.001 & 0.004 & 80 \\
\hline \multirow[t]{3}{*}{2} & Perlakuan II & 0.003 & 0.001 & 0.002 & 67 & $<0.001$ & 0.003 & 100 \\
\hline & Jumlah & 0.008 & 0.001 & 0.007 & 167 & 0.001 & 0.007 & 180 \\
\hline & Rerata & 0.004 & 0.0005 & 0.0035 & 84 & 0.0005 & 0.0035 & 90 \\
\hline
\end{tabular}

Pada tabel 5.4 rerata hasil pemeriksaan kadar residu pestisida (chlorpyrifos) dalam sayur kubis segar (tanpa perlakuan) sebesar $0.004 \mathrm{mg} / \mathrm{kg}$, rerata pada pencucian dengan air bersih mengandung $0.0005 \mathrm{mg} / \mathrm{kg}$ dengan rerata penurunan $0.0035 \mathrm{mg} / \mathrm{kg}(84 \%)$. Sedangkan dalam lalapan kubis pada pencelupan air panas rerata mengandung $0.0005 \mathrm{mg} / \mathrm{kg}$ residu pestisida (chlorpyrifos) dengan rerata penurunan $0.0035 \mathrm{mg} / \mathrm{kg}(90 \%)$.

5. Kadar Residu Pestisida (Chlorpyrifos) Dalam Lalapan Kacang Panjang Berdasarkan Cara Pengolahan

Tabel 5

Hasil Pemeriksaan Residu Pestisida (Chlorpyrifos) Pada Lalapan Kacang Panjang Berdasarkan Cara Pengolahan

\begin{tabular}{|c|c|c|c|c|c|c|c|c|}
\hline \multirow{4}{*}{ No } & \multirow{4}{*}{$\begin{array}{c}\text { Jenis } \\
\text { Sampel }\end{array}$} & \multicolumn{7}{|c|}{ Cara Pengolahan Lalapan Kacang Panjang } \\
\hline & & \multirow{3}{*}{$\begin{array}{c}\text { Tanpa } \\
\text { Perlakuan } \\
\text { (mg/kg) }\end{array}$} & \multicolumn{3}{|c|}{ Dicuci air bersih } & \multicolumn{3}{|c|}{ Dicelup air panas } \\
\hline & & & \multirow{2}{*}{$\begin{array}{c}\text { Kadar } \\
\text { (mg/kg) }\end{array}$} & \multicolumn{2}{|c|}{ Penurunan } & \multirow{2}{*}{$\begin{array}{c}\text { Kadar } \\
\text { (mg/kg) }\end{array}$} & \multicolumn{2}{|c|}{ Penurunan } \\
\hline & & & & kg/mg & $\%$ & & $\mathbf{k g} / \mathbf{m g}$ & $\%$ \\
\hline 1 & Perlakuan I & 0.022 & 0.009 & 0.013 & 59 & 0.003 & 0.019 & 86 \\
\hline \multirow[t]{3}{*}{2} & Perlakuan II & 0.068 & 0.020 & 0.048 & 71 & 0.007 & 0.061 & 90 \\
\hline & Jumlah & 0.090 & 0.029 & 0.061 & 130 & 0.010 & 0.08 & 176 \\
\hline & Rerata & 0.045 & 0.0145 & 0.0305 & 65 & 0.005 & 0.04 & 88 \\
\hline
\end{tabular}


Pada tabel 5.5 rerata hasil pemeriksaan kadar residu pestisida (chlorpyrifos) dalam sayur kacang panjang segar tanpa perlakuan sebesar $0.045 \mathrm{mg} / \mathrm{kg}$, rerata pada pencucian dengan air bersih mengandung $0.0145 \mathrm{mg} / \mathrm{kg}$ dengan rerata penurunan $0.0305(65 \%)$. Sedangkan dalam lalapan kacang panjang pada pencelupan air panas rerata mengandung $0.005 \mathrm{mg} / \mathrm{kg}$ residu pestisida (chlorpyrifos) dengan rerata penurunan $0.04 \mathrm{mg} / \mathrm{kg}(88 \%)$.

\section{PEMBAHASAN}

Pestisida adalah substansi kimia yang digunakan untuk membunuh atau mengendalikan berbagai hama. Pestisida golongan organofosfat adalah pestisida yang tidak persisten dapat diurai di alam menjadi senyawa lain yang tidak berbahaya, penguraian ini dapat berlangsung secara kimiawi atau secara biologis oleh tanaman maupun mikroorganisme. Golongan organofosfat struktur kimianya dan cara kerjanya berhubungan erat dengan saraf.

Kebanyakan pestisida dipakai pada komoditi sayur-sayuran terutama pada sayur kubis. Kubis merupakan sayuran yang sangat rentan terhadap serangan dan jamur dan biasanya disemprot secara rutin dengan frekuensi penyemprotan yang tinggi, bisa sepuluh sampai lima belas kali dalam semusim. Selain itu, kubis biasa dimasak tanpa di kupas sehingga kemungkinan terbawanya pestisida yang menempel di permukaan sayuran sangat besar, apalagi bila permukaan daun yang berlekuk dan berlapis-lapis.

Petani melakukan penyemprotan pestisida jenis Dursban 200 EC pada tanaman kacang panjang dengan tujuan mengatasi hama perusak pada daun dan serangga penghisap pada kacang panjang. Penyemprotan dilakukan pada umur kacang panjang sudah dua bulan (Haryanto, 2008).

Sayuran yang positif mengandung pestisida jika dikonsumsi terus-menerus maka residunya akan terakumulasi dalam tubuh dan dapat berpengaruh terhadap susunan saraf dan akan terkumpul dalam lemak, dengan demikian terpapar dalam waktu yang lama dengan tingkat yang relatif tinggi terhadap pestisida dapat menyebabkan gangguan saraf, degenerasi kelenjar ludah, kelenjar air mata, jaringan pancreas, thymus, limpa dan menghambat cholinestrase dalam darah secara tetap (Depkes RI, 2004). Residu yang tersimpan dalam lemak tidak dapat diekskresi lewat urine, dan akan terus menumpuk hingga dapat merusak jaringan dan dapat menyebabkan kanker (Mukono dalam Latifah, 2003).

\section{Kadar Residu Pestisida (Chlopyrifos) Pada Sayur Segar Tanpa Perlakuan}

Hasil analisa residu pestisida (chlorpyrifos) pada sayur segar tanpa perlakuan yang diambil dari dua pedagang di Pasar Terong Kota Makassar menunjukkan dalam sayur kubis segar didapatkan rerata sebesar $0,004 \mathrm{mg} / \mathrm{kg}$ dan dalam sayur kacang panjang segar didapatkan rerata sebesar $0.045 \mathrm{mg} / \mathrm{kg}$. Berdasarkan batas deteksi pada alat kromatografi gas yang digunakan, hal ini menunjukkan kadar residu pestisida dalam sayur kubis tersebut masih jauh berada di bawah batas maksimum residu pestisida klorpirifos dalam sayuran kubis dan pada kacang panjang melebihi baras maksimum yang ditetapkan oleh Badan Standardisasi Nasional tahun 2008 dalam Standar Nasional Indonesia 7313 : 2008 tentang Batas Maksimum Residu pestisida pada hasil pertanian, untuk kadar klorpirifos pada kubis yaitu $1 \mathrm{mg} / \mathrm{kg}$ dan pada kacang panjang segar sudah melebihi batas maksimum residu pestisida klorpirifos yang diperbolehkan yaitu $0.01 \mathrm{mg} / \mathrm{kg}$.

Pada kubis segar, walaupun masih jauh dari batas maksimum yang diperbolehkan, akan tetapi belum dapat dikatakan aman untuk dikonsumsi karena kadar residu pestisida klorpirifos masih terdeteksi, sedangkan kadar residu klorpirifos pada kacang panjang sudah melebihi batas maksimum yang diperbolehkan, apabila dikomsumsi secara terus menerus dapat terakumulasi dalam tubuh, sehingga menyebabkan gangguan kesehatan, seperti menghambat antikolinesterase, enzim vital untuk sistem jaringan saraf bagi manusia, memberikan efek pada sistem saraf pusat mencakup kebingungan, mengantuk, depresi, susah berkonsentrasi, gagap dalam 
berbicara, insomnia, mimpi buruk, dan menjadi gila. Klorpirifos juga dapat membuat iritasi pada mata dan kulit.

Berdasarkan tabel 5.1 dapat diketahui bahwa residu pestisida (Chlorpyrifos) pada sayur kacang panjang lebih tinggi dibanding residu yang terdapat pada sayur kubis segar. Rendahnya residu pada kubis ini, dikarenakan sayur kubis yang diteliti telah dilakukan pengupasan pada bagian terluar yang kelihatan kotor dan rusak akibat benturan sebelum dipasarkan untuk menjaga kualitas dan tampilan sayur kubis lebih terlihat segar dan berkualitas baik, karena kebanyakan pembeli lebih memperhatikan tampilan luar dari sayur tersebut. Dengan pengupasan ini otomatis akan mengurangi kadar residu pestisida yang kemungkinan lebih banyak terdapat pada beberapa lapisan terluar sayuran kubis. Selain itu, sayur yang menjadi sampel penelitian tidak menghasilkan bau yang tajam seperti halnya sifat fisik dari klorpirifos adalah memiliki bau yang tajam dan tidak menimbulkan adanya butiran kristal putih. Oleh karena itu, kadar residu pestisida pada kubis tersebut sangat rendah.

Hasil pengamatan dan tanya jawab dengan pedagang sayuran kubis di Pasar Terong Kota Makassar menunjukkan bahwa sayuran kubis yang sebagian besar berasal dari Kabupaten Enrekang yang baru diterima oleh pedagang diberikan perlakuan untuk menjaga kualitas dan penampilan dari sayuran kubis. Perlakuan yang diberikan adalah dengan memberikan percikanpercikan air pada sayuran kubis yang tidak langsung terjual pada hari pertama sayuran kubis diterima pedagang. Percikan-percikan air ini juga dapat mengurangi kadar residu pesitisida karena residu pestisida yang ada pada permukaan sayuran kubis dapat jatuh bersama dengan air yang dipercikan pada permukaan sayuran kubis.

Menurut hasil wawancara dan informasi dari berbagai sumber dapat diketahui bahwa kacang panjang yang dijual di Pasar Terong berasal dari
Kabupaten Gowa, Kecamatan Palangga. Dalam penanganan pasca panen, petani hampir $90 \%$ tidak melakukan pencucian terhadap polong kacang panjang. Polong yang telah dipetik langsung dijual, biasanya yang melakukan pencucian adalah pengepul yang bertujuan agar polong tetap kelihatan segar saat akan dijual. Selain itu petani biasanya membuat formulasi pestisida dengan pencampuran 2 atau lebih pestisida dalam sekali penyemprotan. Hal tersebut menyebabkan hasil analisa laboratorium bahan aktif pestisida pada kacang panjang cukup tinggi dan melebihi ambang batas maksimum yang diperbolehkan.

Hasil pemeriksaan residu pestisida klorpirifos dalam sayuran kol yang dilakukan di Laboratorium Pengujian Pestisida UPTD Balai Proteksi Tanaman Pangan dan Hortikultura Provinsi Sulawesi Selatan menunjukkan bahwa sayuran kol mentah yang dijual di Pasar Terong Kota Makassar menunjukkan hasil $\leq 0,1 \mathrm{mg} / \mathrm{kg}$ berdasarkan batas deteksi pada alat kromatografi gas yang digunakan. Hal ini sejalan dengan hasil analisa residu pestisida (chlorpyrifos) pada kubis menunjukkan bahwa kadar residu pestisida klorpirifos pada sampel sayur tersebut masih berada di bawah 0,1 $\mathrm{mg} / \mathrm{kg}$ atau juga terdapat kemungkinan pada sampel sayur tersebut tidak mengandung residu pestisida klorpirifos. Sayuran kol mentah dari Pasar Terong Kota Makassar masih berada di bawah BMR pesitisida klorpirifos, tetapi belum dapat dikatakan aman untuk dikonsumsi karena masih ada kemungkinan terdapatnya senyawa atau residu pestisida lain mengingat penelitian ini hanya mengidentifikasi satu jenis bahan aktif pestisida yaitu klorpirifos.

Hasil penelitian residu pestisida (chlorpyrifos) dalam kacang panjang yang dijual di Pasar Terong Kota Makassar ini tidak sejalan dengan hasil penelitian pestisida dari Mustafa, Anwar Daud dan Makmur Selomo tahun 2013 di Pasar Pannampu dan Lotte Mart yakni kadar residu klorpirifos tidak terdeteksi 
sedangkan pada penelitian di Pasar Terong didapatkan kadar residu yang melebihi ambang batas maksimum yang diperbolehkan meskipun sumber kacang panjang bersumber dari tempat yang sama yaitu berasal dari Kabupaten Gowa, Kecamatan Pallangga.

2. Kadar Residu Pestisida (Chlorpyrifos) Dalam Lalapan Dengan Pencucian Air Bersih

Analisa residu pestisida klorpirifos dalam lalapan dengan cara pengolahan yaitu sayur berupa kubis dan kacang panjang di cuci dengan air bersih mengalir sebanyak tiga kali bilas, hal tersebut dilakukan pada sayur yang berasal dari dua pedagang sayur di Pasar Terong Kota Makassar, sehingga perlakuan dalam Ialapan dengan pencucian air bersih dilakukan dua kali. Perlakuan dengan pencucian air bersih pada sayur kubis dan kacang panjang merupakan cara yang paling umum dilakukan untuk membuat lalapan, cara tersebut merupakan cara paling mudah dan murah yang biasa dilakukan para pedagang makanan yang menyediakan lalapan dalam menu jualannya.

Berdasarkan tabel 5.2 didapatkan rerata residu pestisida (chlopyrifos) dalam lalapan kubis dengan pencucian air bersih sebesar $0,0005 \mathrm{mg} / \mathrm{kg}$ dan rerata residu dalam lalapan kacang panjang dengan pencucian air bersih sebesar $0.0145 \mathrm{mg} / \mathrm{kg}$. Rerata kadar residu pestisida (chlorpyrifos) pada kacang panjang lebih tinggi dibanding pada kubis setelah sayuran tersebut dicuci dengan air bersih. Hal tersebut disebabkan kadar awal residu pestisida (chlorpyrifos) sebelum pencucian lebih tinggi pada kacang panjang dibanding pada kubis.

Dari hasil Pengujian pestisida yang dilakukan terhadap Sayuran kol siap santap di Kantin Jasper Unhas Makassar menunjukkan hasil $\leq 0,1$ $\mathrm{mg} / \mathrm{kg}$ berdasarkan batas deteksi pada alat kromatografi gas yang digunakan. Hal ini menunjukkan bahwa kadar residu pestisida klorpirifos dalam sampel sayur tersebut masih berada di bawah 0,1 $\mathrm{mg} / \mathrm{kg}$ atau juga terdapat kemungkinan pada sampel sayur tersebut tidak mengandung residu pestisida klorpirifos, namun masih ada kemungkinan terdapatnya senyawa atau residu pestisida lain mengingat penelitian ini hanya mengidentifikasi satu jenis bahan aktif pestisida yaitu klorpirifos (Elvinali Herdariani, Anwar Daud, Makmur Selomo, 2013).

Meskipun hasil tersebut masih dibawah Batas Maksimum Residu (BMR) SNI tahun 2008 tentang pestisida pada pertanian. Residu pestisida untuk golongan klorpirifos pada kubis adalah sebesar $1 \mathrm{mg} / \mathrm{kg}$ dan pada kacang panjang $0.01 \mathrm{mg} / \mathrm{kg}$ masih dikategorikan aman, hal ini perlu diwaspadai mengingat bahaya klorpirifos pada manusia, seperti efek terhadap sistem saraf pusat mencakup kebingungan, mengantuk, depresi, susah berkonsentrasi, gagap dalam berbicara, insomnia, mimpi buruk, dan menjadi gila. Klorpirifos juga dapat membuat iritasi pada mata dan kulit. Gejala tersebut akan berbeda untuk setiap yang terpapar tergantung pada dosis terpapar, lamanya terpapar, dan bagaimana ia terpapar.

3. Kadar Residu Pestisida (Chlorpyrifos) Dalam Lalapan Dengan Pencelupan Pada Air Panas

Analisa residu pestisida klorpirifos dalam lalapan dengan cara pengolahan yaitu sayur berupa kubis dan kacang panjang di cuci dengan air bersih mengalir sebanyak dua kali bilas, lalu dicelup pada air panas selama 5 menit, kemudian ditiriskan. Hal tersebut dilakukan pada sayur yang berasal dari dua pedagang sayur di Pasar Terong Kota Makassar, sehingga perlakuan dalam lalapan dengan pencelupan pada air panas dilakukan dua kali. Perlakuan dengan pencelupan pada air panas pada sayur kubis dan kacang panjang merupakan cara lain dalam pengolahan lalapan yang seringkali dilakukan oleh pedagang yang menyediakan Ialapan dalam menunya. Cara ini bertujuan untuk membersihkan makanan dari kotoran yang menempel juga untuk menginaktifkan enzim-enzim pada makanan yang merupakan nutrisi bagi 
bakteri, sehingga cara pengolahan ini juga untuk mengurangi bakteri pada lalapan dan menjadikannya lebih awet.

Pada tabel 5.3 diketahui hasil pemeriksaan kadar residu pestisida (chlorpyrifos) dalam lalapan dengan pencelupan air panas pada kubis dengan rerata $0.0005 \mathrm{mg} / \mathrm{kg}$ lebih rendah dibanding kadar residu pestisida (chlorpyrifos) pada kacang panjang dengan rerata sebesar $0.005 \mathrm{mg} / \mathrm{kg}$. Hal tersebut disebabkan kadar residu pestisida (chlorpyrifos) pada sayur segar sebelum perlakuan pada sayur kubis memiliki kadar yang jauh lebih rendah dibanding pada sayur kacang panjang.

4. Kadar Residu Pestisida (Chlorpyrifos) Dalam Lalapan Kubis Berdasarkan Cara Pengolahan

Pada tabel 5.4 dapat diketahui bahwa rerata kadar residu pestisida (chlorpyrifos) dalam lalapan kubis pada pencucian dengan air bersih dan pencelupan pada air panas dengan rerata $0.0005 \mathrm{mg} / \mathrm{kg}$ yang berarti terjadi penurunan jauh dari BMR sesuai SNI 7313. Meskipun rerata kadar residu sama dari kedua perlakuan namun penuran pada penggunaan air bersih lebih rendah yakni $84 \%$ dibanding dalam lalapan kubis pada pencelupan dengan air panas yang dapat turun sampai $90 \%$. $\mathrm{Hal}$ tersebut tidak lepas dari kandungan awal residu pestisida yang lebih tinggi pada perlakuan pertama.

Penurunan jumlah residu pestisida dipengaruhi oleh beberapa faktor, yaitu (1) daya larut. Residu pestisida dapat melarut pada air pencuci. Hal ini, berkaitan dengan sifat fisik dan kimia, yaitu kelarutan dalam air dan $\mathrm{pH}$ air pencuci. (2) Hidrolisis. Residu pestisida dapat terhidrolisis tergantung pada jumlah air yang ada, $\mathrm{pH}$ dan konsentrasi insektisida. (Amvrazi, 2011) Pestisida golongan organophosphat seperti klorpirifos mempunyai tingkat kelarutan $0.0014 \mathrm{gr} / \mathrm{L}$ pada suhu $25^{\circ} \mathrm{C}$, selain itu senyawa klorpirifos memiliki waktu paruh yang cepat pada kondisi iklim tropis, sehingga penurunan kadar pestisida (chlorpyrifos) pada pencelupan air panas lebih tinggi dibanding pada pencucian dengan air bersih.

Hal tersebut sejalan dengan penelitian Maruli, A, Santi, D.N dan Naria, E tahun 2012 bahwa penurunan terbesar kadar residu pestisida pada kubis adalah pada cara pencucian dengan air mengalir dan perebusan, sedangkan penurunan terkecil adalah cara pencucian menggunakan air rendaman PAM.

5. Kadar Residu Pestisida (Chlorpyrifos) Dalam Lalapan Kacang Panjang Berdasarkan Cara Pengolahan

Berdasarkan tabel 5.5 dapat diketahui bahwa rerata hasil pemeriksaan kadar residu pestisida (chlorpyrifos) dalam sayur kacang panjang pada pencucian dengan air bersih sebesar $0.0145 \mathrm{mg} / \mathrm{kg}$ yang berarti masih melebihi BMR sesuai SNI 7313 tahun 2008, dengan rerata penurunan 0.0305 (65\%). Sedangkan dalam lalapan kacang panjang pada pencelupan air panas rerata mengandung $0.005 \mathrm{mg} / \mathrm{kg}$ dan sudah memenuhi BMR sesuai SNI 7313. Residu pestisida (chlorpyrifos) dengan rerata penurunan $0.04 \mathrm{mg} / \mathrm{kg}$ (88\%). Sehingga dapat dikatakan bahwa dalam lalapan kacang panjang terjadi penurunan kadar residu pestisida (chlorpyrifos) lebih besar pada pencelupan air panas dibanding pada pencucian dengan air bersih.

Senyawa klorpirifos memiliki waktu paruh yang cepat pada kondisi iklim tropis. Menurut Ngan (2005) dalam Maruli (2012), terdapat perbedaan waktu paruh antara kondisi iklim tropis dengan iklim yang bukan tropis, iklim tropis membuat waktu paruh yang ada menjadi lebih cepat. Perbedaan perlakuan pencucian mempunyai pengaruh yang signifikan terhadap tingkat penurunan residu pestisida. Menurut Amvrazi (2011) dalam Maruli (2012).

Tinggi rendahnya residu pestisida pada tanaman ditentukan oleh jenis pestisida, teknik aplikasi, jenis tanaman, iklim dan cuaca serta penanganan pasca panen. 


\section{KESIMPULAN DAN SARAN KESIMPULAN}

1. Rerata kadar residu pestisida (chlorpyrifos) dalam sayur segar tanpa perlakuan pada kubis sebesar 0.004 $\mathrm{mg} / \mathrm{kg}$ dan kacang panjang sebesar $0.045 \mathrm{mg} / \mathrm{kg}$.

2. Rerata kadar residu pestisida (chlorpyrifos) dalam lalapan yang diolah dengan pencucian air bersih pada kubis sebesar $0.0005 \mathrm{mg} / \mathrm{kg}$ dengan rerata penurunan $84 \%$ dan kacang panjang sebesar $0.0145 \mathrm{mg} / \mathrm{kg}$ dengan rerata penurunan $65 \%$.

3. Rerata kadar pestisida (chlorpyrifos) dalam lalapan yang diolah dengan pencelupan air panas pada kubis sebesar $0.0005 \mathrm{mg} / \mathrm{kg}$ dengan rerata penurunan $90 \%$ dan kacang panjang sebesar $0.005 \mathrm{mg} / \mathrm{kg}$ dengan rerata penurunan $88 \%$

\section{SARAN}

1. Sebaiknya pengolah makanan utamanya lalapan kubis dan kacang panjang menggunakan metode pencelupan pada air panas agar kadar residu pestisida (chlorpyrifos) pada lalapan dapat diturunkan sesuai SNI 7313 tahun 2008 tentang BMR residu pestisida klorpirifos.

2. Lalapan kubis lebih relatif aman dikonsumsi dibanding dengan lalapan kacang panjang dilihat dari kadar residu pestisida (chlorpyrifos).

3. Dinas pertanian sebaiknya lebih memperketat pengawasan penggunaan pestisida pada petani sayur, utamanya pada petani kacang panjang. Serta perlu meningkatkan intensitas penyuluhan tentang penggunaan pestisida yang lebih ramah lingkungan.

\section{DAFTAR PUSTAKA}

Amvrazi, EG. 2011. Fate of Pesticide Residues on Raw Agricultural Crops after Postharvest Storage and Food Processing to Edible Portions, Pesticides-Formulation, Effect, Fate, Margarita Stoycheva (Ed) ISBN : 978-953-307-532-7, Intech, http://Intech
open.com//Books/Pesticides-

formulation-effect-fate/fate-of-

pesticides-residues-onraw-

agricultural-crops-after

postharvest-storage-and-food-

processing. Diakses tanggal 18

Agustus 2012.

Dinas Pertanian Tanaman Pangan

Kabupaten Gowa. 2005. Laporan

Tahunan. Dinas Pertanian Tanaman

Pangan Kabupaten Gowa.

Dinas Pertanian Tanaman Pangan

Kabupaten Gowa. 2006. Laporan

Tahunan. Dinas Pertanian Tanaman

Pangan Kabupaten Gowa.

Direktorat Jenderal Prasarana dan Sarana

Pertanian. 2011. Pedoman

Pembinaan Penggunaan pestisida.

Direktorat Jenderal Prasarana dan

Sarana Pertanian, Direktorat Pupuk, Kementrian Pertanian.

Elvinali Herdariani, Anwar Daud, Makmur Selomo. (elvinaliherdariani@yahoo. co.id/082187718926). 2013.

Identifikasi Residu Pestisida Klorpirifos dalam Sayuran KolMentah di Pasar Terong Kota Makassar dan Sayuran Kol Siap Santap di Kantin Jasper Universitas Hasanuddin

Makassar. (http://repository.unhas.ac.id/bitstrea m/handle/123456789/8620/JURNAL $\% 20$ ELVIN

LI\%20HERDARIANI.pdf?sequence= 1, diakses tanggal 7 Januari 2016). html

Maruli, A., Santi, D. N., \& Naria, E., 2012. Analisa kadar residu insektisida golongan organofosfat pada kubis (brassica oleracea) setelah pencucian dan pemasakan di Desa Dolat Rakyat Kabupaten Karo tahun 2012. (onlinejurnal). http://jurnal.usu.ac.id/index.php/lkk/a rticle/view/1635/937. diakses 2 Juni $\underline{2013}$. 
Mustafa, Anwar Daud, Makmur Selomo. 2013. Identifikasi Residu Pestisida Klorpirifos dan Metidation Dalam Kacang Panjang di Pasar Pannampu dan Lotte Mart Kota Makassar.

Zainul Fadila. 2013. Efek Neurobehavioral dan Faktor Determinannya pada Petani Penyemprot Tanaman Sayur dengan Pestisida di Desa Perbawati
Kabupaten Sukabumi Tahun 2013. (onlinejurnal). http://repository.uinjkt .ac.id/dspace/bitstream/123456789/ 25906/1/ZAINUL\%20FADILAHfkik.pdf, diakses 12 Januari 2016). Zhang Z.Y, et al. 2007. Pesticides Residue in Spring Cabbage (Brassica bleracea L. var.capita) Grown In Open Field. J. Foodcont. 1816): 723-730. 